\title{
FUNGSI SEKTOR UNGGULAN INDUSTRI TERHADAP PERTUMBUHAN EKONOMI DELI SERDANG
}

\author{
M. Nasir \\ Fakultas Ekonomi Universitas Negeri Medan, Indonesia \\ Email: nasir_muhammad11@yahoo.co.id
}

\begin{abstract}
Deli Serdang area surrounds the capital of North Sumatra Medan, there are industrial concentration of industrial concentration in Sunggal sub-district, Tanjung Morawa sub district, Percut Sei Tuan sub-district, on the other side of industry sector contribute greatly to society prosperity level of Deli Serdang which is $32,12 \%$. The problem is how much influence the industrial sector has on the economic growth in Deli Serdang. The purpose of this study to determine the magnitude of the influence of industrial sector on economic growth Deli Serdang. The industrial sector has a value of $L Q>1$ means the industrial sector is a leading sector for Deli Serdang. To know the magnitude of industrial sector influence on the economic growth, linear regression model is used. This study uses time series data from 1993-2015 taken from BPS North Sumatra. The result of analysis shows that $15 \%$ of economic growth variation can be explained by industry sector while $85 \%$ is explained by other independent variable which is not included in research model. The value of these negative constants shows that without the leading sector of the industry the economic growth in deli serdang decreases. The estimation result of Deli Serdang's economic growth function is influenced by the industry's leading sectors having a positive and significant influence with $95 \%$ confidence level..
\end{abstract}

Keywords: industry's flagship sector, economic growth.

\section{PENDAHULUAN}

umlah barang - jasa yang diproduksi oleh suatu daerah dimuat dalam tabel yang dinamakan dengan PDRB, tabel ini menunjukan seluruh jumlah barang - jasa yang diproduksi pada suatu daerah selama periode tertentu biasanya selama satu tahun. Tabel PDRB bila dipilah berisikan 17 sektor ekonomi salah satu sektor tersebut adalah sektor industri pengolahan. Sektor ini mengolah bahan baku diproses menghasilkan produk - produk berupa barang jadi ataupun barang setengah jadi. Untuk mengetahui gambaran ekonomi Deli Serdang apakah terjadi kelebihan produksi barang-jasa ataupun kekurangan barang-jasa

$$
\text { QE Journal |Vol.06 - N } 0.02 \text { July } 2017 \text { - } 103
$$


perlu kiranya membandingkan angka - angka PDRB. Sumatera Utara sebagai wilayah lebih luas, kota Medan sebagai wilayah tetangga dan Deli Serdang wilayah yang diteliti dari sini dapat diketahui keberhasilan ekonomi Deli Serdang bila disetarakan dengan ekonomi Sumatera Utara dan ekonomi kota madya Medan sebagai daerah tetangganya. Tingkat kesejahteraan masyarakat dapat juga dilihat dari PDRB, dengan meningkatnya PDRB berarti terjadi pertumbuhan ekonomi pada suatu wilayah dengan kata lain terjadi peningkatan kesejateraan pada masyarakat diwilayah tersebut. Berikut distribusi persentase tiga sektor ekonomi dominan dari PDRB menurut lapangan usaha ADH konstan tahun 2010 Sumatera Utara, Medan dan Deli Serdang tahun 2013-2015.

Tabel 1. Distribusi Persentase 3 Sektor Ekonomi Dominan Dari PDRB Menurut Lapangan Usaha ADH Konstan 2010 Sumatera Utara, Medan dan Deli Serdang Tahun 2013-2015 (\%)

\begin{tabular}{llllllllll}
\hline Sektor & \multicolumn{3}{l}{ Sumatera Utara } & \multicolumn{3}{l}{ Medan } & \multicolumn{4}{c}{ Deli Serdang } \\
\cline { 2 - 10 } Dominan & $\mathbf{2 0 1 3}$ & $\mathbf{2 0 1 4}$ & $\mathbf{2 0 1 5}$ & $\mathbf{2 0 1 3}$ & $\mathbf{2 0 1 4}$ & $\mathbf{2 0 1 5}$ & $\mathbf{2 0 1 3}$ & $\mathbf{2 0 1 4}$ & $\mathbf{2 0 1 5}$ \\
\hline Pertanian & 25,05 & 24,85 & 24,97 & 1,20 & 1,19 & 1,19 & 13,01 & 12,31 & 12,24 \\
Industri & 20,23 & 19,79 & 19,52 & 16,47 & 16,17 & 15,54 & 33,89 & 32,65 & 32,12 \\
$\begin{array}{l}\text { Pengolahan } \\
\text { Perdagangan }\end{array}$ & 17,31 & 17,59 & 17,47 & 23,83 & 24,67 & 24,77 & 16,50 & 16,41 & 16,53 \\
\hline
\end{tabular}

Sumber : BPS Sumatera Utara

Sebagai perbandingan untuk wilayah yang lebih luas Sumatera Utara tahun 2013 sektor pertanian menyumbang pada PDRB sebesar 25,05\%, pada tahun 2014 berkurang menjadi $24,85 \%$ selanjutnya pada tahun 2015 terjadi peningkatan berubah menjadi $24,97 \%$. Untuk sektor industri pengolahan pada tahun 2013 memberi sumbangan kepada PDRB sebesar 20,23\%, pada tahun 2014 terjadi perubahan yaitu menurun berubah menjadi 19,79\%, pada tahun 2015 terjadi penurunan lagi berubah menjadi $19,52 \%$. Berikutnya sektor perdagangan besar, eceran, reperasi mobil dan sepeda motor pada tahun 2013 menyumbang pada PDRB sebesar 17,31\% pada tahun 2014 terjadi peningkatan berubah menjadi 17,59\% dan pada tahun 2015 terjadi penurunan berubah menjadi 17,47\%. Berubahnya sumbangan dari sektor ekonomi tersebut karena adanya fluktuasi ekonomi di Sumatera Utara

Sebagai perbandingan pada perekonomian kota Medan sebagai wilayah tetangga pada tahun 2013 sektor pertanian menyumbang pada PDRB Kota

$$
\text { Q E J ournal | Vol.06 - N } 0.02 \text { July } 2017 \text { - } 104
$$


Medan sebesar 1,20\% pada tahun 2014 terjadi penurunan berubah menjadi 1,19\% dan pada tahun 2015 tidak terjadi perubahan yaitu tetap sebesar 1,19\%. Pada sektor industri pengolahan tahun 2013 menyumbang pada PDRB Kota Medan sebesar 16,47\%, pada tahun 2014 terjadi penurunan berubah menjadi 16,17\%. Pada tahun 2015 terjadi penurunan berubah menjadi 15,54\%, sektor ini turun terus selama 3 tahun berturut-turut. Berikut sektor perdagangan besar, eceran, reparasi mobil dan sepeda motor pada tahun 2013 memberi sumbangan pada PDRB Kota Medan sebesar 23,83\% dan pada tahun 2014 terjadi penambahan berubah menjadi $24,67 \%$ dan pada tahun 2015 terjadi peningkatan lagi berubah menjadi 24,77\% sektor ini selama 3 tahun berturut-turut terjadi peningkatan.

Selanjutnya perekonomian Deli Serdang sebagai tempat penelitian ini dilakukan sektor pertanian memberi sumbangan pada PDRB sebesar 13,01\%, pada tahun 2014 terjadi penurunan berubah menjadi 12,31\% dan pada tahun 2015 terjadi penurunan lagi berubah menjadi 12,24\% sektor pertanian selama 3 tahun berturut-turut mengalami penurunan menunjukkan adanya perubahan pola, sektor pertanian semakin kecil peranannya dalam struktur perokonomian Deli Serdang. Pada sektor industri pengolahan tahun 2013 memberi sumbangan pada PDRB Deli Serdang sebesar 33,89\%. Pada tahun 2014 terjadi penurunan berubah 32,65\% dan pada tahun 2015 terjadi penurunan lagi berubah menjadi $32,12 \%$, sektor ini mengalami penurunan terus-menerus selama 3 tahun berturut-turut. Penurunan ini disebabkan adanya gangguan pada sektor industri di Deli Serdang. Berikutnya sektor perdagangan besar, eceran, reparasi mobil dan sepeda motor pada tahun 2013 memberi sumbangan pada PDRB Deli Serdang sebesar 16,50\% dan pada tahun 2014 terjadi penurunan berubah menjadi 16,41\% dan pada tahun 2015 terjadi peningkatan berubah menjadi 16,52\% sektor ini mengalami fluktuasi.

Untuk menambah tingkat kemakmuran masyarakat perlu dilakukan perubahan sektor ekonomi, sektor industri harus lebih besar sumbangannya terhadap PDRB Deli Serdang, hal ini disebabkan sektor industri dapat meningkatkan nilai tambah suatu produk. Sektor ekonmi yang memiliki keunggulan dalam satu wilayah dapat berfungsi sebagai penggerak perekonomian bagi wilayah tersebut. Dikatakan unggul suatu sektor ekonomi dikarenakan hasil perbandingan dari sektor ekonomi yang ada dalam PDRB suatu wilayah dibandingkan dengan seluruh nilai sektor 
ekonomi yang ada dalam PDRB kemudian dibandingkan lagi dengan wilayah yang lebih luas lagi, bila hasil perbandingan ini lebih besar dari satu ini artinya sektor ekonomi ini (sektor i) jumlahnya cukup dan berlebih untuk memenuhi kebutuhan dari wilayah tersebut, kelebihannya diperdagangkan ke wilayah tetangga. Penerimaan dari hasil perdagangan tersebut merupakan pendapatan yang dapat meningkatkan kesejahteraan masyarakat di wilayah tersebut.

Dilatar belakangi oleh fenomena yang telah diutarakan maka dapatlah ditarik masalah dari penelitian ini, apakah sektor ekonomi industri memiliki nilai keunggulan dan apakah berpengaruh signifikan terhadap peningkatan ekonomi di Deli Serdang. Dari masalah ini dapat dibuat tujuan dari penelitian ini yaitu untuk mengetahui sektor ekonomi industri memiliki keunggulan dan pengaruhnya terhadap peningkatan kesejahteraan masyarakat di Deli Serdang.

Setiap wilayah mencatat seluruh jumlah barang dan jasa yang dihasilkan daerah tersebut, pencatatan tersebut dilakukan dalam suatu laporan untuk tingkat daerah dinamakan PDRB (Produk Domestic Regional Bruto) sedangkan untuk tingkat nasional (negara) dinamakan GNP (Gross National Product) laporan ini dilakukan penyusunan dalam periode tertentu biasanya satu tahun sekali. Laporan ini terdiri dari 17 sektor yaitu 1. sektor pertanian, kehutanan dan perikanan, 2. sektor pertambangan dan penggalian, 3. sektor industri pengolahan, 4. sektor pengadaan listrik dan gas, 5. pengadaan air, pengolahan sampah dan daur ulang, 6. Konstruksi, 7. Perdagangan besar dan eceran, reparasi mobil dan sepeda motor, 8. Transportasi dan pergudangan, 9. penyediaan akomodasi dan makanan minuman, 10. Informasi dan komunikasi, 11. Jasa keuangan dan asuransi, 12. Real estate, 13. Jasa perusahaan, 14. Administrasi pemerintahan, pertahanan dan jaminan social wajib, 15. Jasa pendidikan, 16. Jasa kesehatan dan kegiatan social, 17. Jasa lainnya. Membandingkan diantara sektor-sektor yang telah dikemukakan tadi untuk setiap wilayah yang lebih rendah dengan wilayah yang lebih luas lagi diperoleh rasio location quotient (LQ) rumusnya dapat ditunjukkan sebagai berikut:

$$
L Q=\frac{\frac{x i}{B D R E}}{\frac{X i}{G N P}}
$$

Sumber : Tarigan Robinson 2012 
Keterangan :

xi : Nilai sektor i pada suatu wilayah.

PDRB : Produk Domestik Regional Bruto Daerah tersebut

$\mathrm{Xi} \quad$ : Nilai sektor i pada wilayah yang lebih luas.

GNP : Produk Nasional Bruto.

Hasil perhitungan tersebut mejelaskan bahwa:

LQ > 1 : mempunyai arti bahwa sektor i diwilayah yang dihitung ini memiliki nilai lebih (sektor unggul) dibandingkan dengan wilayah pada tingkat yang lebih luas lagi, ini berarti bahwa sektor i surplus sehingga dapat diperdagangkan ke wilayah lain, ini berarti dapat menigkatkan pertumbuhan ekonomi wilayah.

LQ $<1$ : mempunyai arti bahwa sektor i diwilayah yang dihitung ini memiliki nilai kecil bila dibandingkan dengan wilayah pada tingkat yang lebih luas, artinya sektor ini tidak dapat memenuhi kebutuhan wilayah ini sendiri, untuk menutupinya harus didatangkan dari wilayah lain. Ini artinya terjadi kebocoran.

Analisis LQ sektor industri dapat dihitung secara time series hasilnya dapat di regress dengan data pertumbuhan ekonomi di Deli Serdang, hasilnya dapat mendeskripsikan dan mengestimasi pengaruh sektor indusrti terhadap pertumbuhan ekonomi di Deli Serdang.

Model Pertumbuhan Interegional merupakan pengembangan dari teori basis ekspor yaitu dengan memperhitungkan pengaruh ekonomi dari antar wilayah melalui kegiatan perdagangan antar wilayah. Model pertumbuhan ekonomi interregional didasari oleh model pendapatan yang dikemukakan oleh Keynes, persamaannya sebagai berikut

$$
\mathrm{Y}_{i}=\mathrm{C}_{\mathrm{i}}+\mathrm{I}_{\mathrm{i}}+\mathrm{G}_{\mathrm{i}}+\left(\mathrm{X}_{\mathrm{i}}-\mathrm{M}_{\mathrm{i}}\right)
$$

Persamaan (2) dapat diurai menjadi

$$
\mathrm{C}_{\mathrm{i}}=\mathrm{a}+\mathrm{b} \mathrm{Y}_{\mathrm{i}}
$$

Dimana

$\mathrm{C}_{\mathrm{i}}=$ Konsumsi

$\mathrm{a}=$ Tingkat konsumsi minimum

$\mathrm{b}=$ MPC

$\mathrm{Y}=$ Pendapatan 
Persamaan ekspor dan impor untuk masing masing wilayah adalah

$$
\begin{aligned}
& \mathrm{X}_{\mathrm{i}}=\sum_{j=1}^{n} m_{i j} y_{j} \\
& \mathrm{M}_{\mathrm{i}}=\sum_{j=1}^{n} m_{j i} y_{i} .
\end{aligned}
$$

$\mathrm{m}=$ marginal prospensity to impor

persamaan penerimaan wilayah (pajak) adalah sebagai berikut

$$
Y_{i}=Y_{i}\left(1-t_{i}\right) \text {. }
$$

ti persentase pemungutan pajak daerah $\mathrm{i}$

Pengeluaran investasi dan pengeluaran pemerintah diasumsikan sebagai variabel autonomous yang ditetapkan diluar dari model ini dapat ditulis sebagai berikut

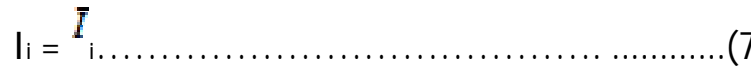

$$
\begin{aligned}
& \mathrm{Gi}_{\mathrm{i}}=\bar{G}_{\mathrm{i}}
\end{aligned}
$$

Dari sini dapat dituliskan pengeluaran total autonomous untuk wilayah $\mathrm{A}_{\mathrm{i}}$ dapat dituliskan sebagai berikut

$$
\mathrm{A}_{\mathrm{i}}=\mathrm{ai}+\bar{I}_{\mathrm{I}}+\bar{G}_{\mathrm{i}}
$$

Dari persamaan yang dikemukakan diatas diperoleh persamaan pendapatan regional sebagai berikut

$$
\mathrm{Y}_{\mathrm{i}}=\frac{\left[A_{i}+\Sigma_{j=1}^{n} m_{i j} y_{j}\left(1-t_{j}\right]\right.}{\left[1-\left(c_{i} \Sigma_{j=1}^{n} m_{j i}\right)(1-t)\right]}
$$

(Syafrizal, 2012).

Persamaan tersebut menunjukkan bahwa pendapatan suatu wilayah terdiri dari penjumlahan pengeluaran autonomous ditambah dengan jumlah ekspor wilayah dan dikalikan dengan angka multiplier regional hal ini berdampak langsung terhadap pertumbuhan ekonomi suatu wilayah.

\section{METODE PENELITIAN}

Penelitian ini menghitung nilai LQ sektor industri di Deli Serdang, data yang digunakan bersifat expost facto secara time series sejak tahun 1993- 
2015. Sumber data berasal dari PDRB Sumatera Utara dan PDRB Deli Serdang.

\section{Alat Analisis - Statistik Deskriptif}

Alat ini digunakan untuk menggambarkan fenomena perekonomian Deli Serdang Serta tingkat kesejahteraan masyarakatnya.

\section{Ordinary Least Squares (OLS)}

Alat analisis ini dipergunakan untuk mengetahui besarnya pengaruh sektor industri terhadap pertumbuhan ekonomi Deli Serdang model yang digunakan adalah sebagai berikut : $\Delta y=\alpha_{0}+\alpha_{1} X_{1}+\epsilon$

Dimana:

$\Delta y \quad$ : Pertumbuhan Ekonomi

$\mathrm{X}_{1}$ : Nilai LQ dari Sektor Industri

$\alpha_{0}$ : Konstanta

$\alpha_{1}:$ Koefisien estimasi

$\epsilon \quad$ : error Term

\section{HASIL DAN PEMBAHASAN}

Perekonomian Deli Serdang Sektor Industri terdapat pada lokasi tertentu, yaitu di kecamatan Sunggal, kecamatan Tanjung Morawa dan kecamatan Percut Sei Tuan. Kabupaten Deli Serdang lokasinya mengelilingi ibu kota Provinsi Sumatera Utara Medan, Berbagai fasilitas infrastruktur perhubungan darat, laut dan udara cukup baik untuk mendukung perkembangan sektor industri. Kontribusi sektor industri terhadap PDRB Deli Serdang cukup besar yaitu 32,27\% dengan nilai sebesar Rp 27.251.000.000.000,--. Sumbangan ini berasal dari sub sektor industri makanan dan minuman sebesar 19,34\% dan sub sektor industri karet, barang dari karet dan pelastik sebesar 4,79\% serta sub sektor industri lainnya sebesar 8,14\%. Sektor industri memiliki kemampuan untuk meningkatkan kesejahteraan masyarakat hal ini desebabkan sektor industri, mampu meningkatkan nilai tambah dari bahan baku menjadi produk jadi ataupun produk setengah jadi yang mempunyai nilai lebih tinggi dari sebelumnya. Kemudian sektor industri mampu menyerap modal untuk investasi, kegiatan investasi dapat mendorong terjadinya pertumbuhan ekonomi, teori pertumbuhan menyatakan bahwa dengan adanya pemupukan modal maka akan meningkatkan investasi. Selain itu 
investasi merupakan salah satu dari variabel yang mempengaruhi dan menyerap tenaga kerja yang besar untuk bekerja pada sektor industri. Berikut jumlah Idustri Besar, Sedang yang ada di Deli Serdang.

Tabel 2. Jumlah Industri Besar, Sedang di Beberapa Kecamatan Dominan Deli Serdang Tahun2016

\begin{tabular}{llll}
\hline $\begin{array}{c}\text { Wilayah Kecamatan } \\
\text { Dominan }\end{array}$ & Industri Besar & Industri Sedang & $\begin{array}{c}\text { Industri Besar- } \\
\text { Sedang }\end{array}$ \\
\hline Tanjung Morawa & 50 & 59 & 109 \\
Sunggal & 31 & 103 & 134 \\
Percut.Sei.Tuan & 13 & 25 & 38 \\
Lainnya & 19 & 68 & 187 \\
Jumlah & 113 & 255 & 368 \\
\hline
\end{tabular}

Sumber: BPS Deli Serdang 2016

Jumlah perusahan industri baik besar maupun sedang yang berlokasi di Deli Serdang ada sebanyak 736 perusahan menyebar pada tiga kecamatan yang dominan, kecamatan Tanjung Morawa terdapat 218 perusahan, Kecamatan Sunggal ada 268 perusahan, Kecamatan Percut.Sei Tuan ada 76 perusahaan sisa lainnya sebesar 274 perusahan menyebar pada kecamatan-kecamatan lain yang ada di Deli Serdang. Jumlah industri manufaktur makanan merupakan terbesar yaitu sebanyak 86 perusahaan kemudian industri karet, barang dari karet dan plastic sebanyak 84 perusahaan. Perusahaan industri kayu, barang dari kayu dan gabus (tidak termasuk barang anyaman dari bambu, rotan dan sejenisnya) sebanyak 38 perusahaan. Jumlah tenaga kerja yang diserap sektor industri di Deli Serdang dapat dilihat pada tabel 3 berikut :

Tabel 3. Jumlah Tenaga Kerja yang Bekerja Pada Sektor Industri Besar dan Sedang di Kecamatan Dominan Deli Serdang Tahun 2016.

\begin{tabular}{lccc}
\hline $\begin{array}{c}\text { Wilayah } \\
\text { Kecamatan } \\
\text { Dominan }\end{array}$ & $\begin{array}{c}\sum \text { T Kerja Indutri } \\
\text { besar }\end{array}$ & $\begin{array}{c}\sum \text { T. Kerja } \\
\text { Industri Sedang }\end{array}$ & $\begin{array}{c}\sum \text { T.Kerja Industri } \\
\text { besar-Sedang }\end{array}$ \\
\hline Tanjung Morawa & 18070 & 3012 & 21082 \\
Sunggal & 7017 & 5655 & 12672 \\
Percut Sei.Tuan & 4210 & 1097 & 5307 \\
Lainnya & 6164 & 2401 & 8565 \\
Jumlah & 35461 & 12165 & 47626 \\
\hline & & QE J ournal |Vol.06 - N 0. 02 July 2017 - 110
\end{tabular}


Sumber: BPS Deli Serdang

Dari tabel 3 diatas jenis industri Besar - Sedang yang paling besar daya serap tenaga kerja yaitu sebesar 47626 pekerja, berikut Industri besar yaitu sebesar 35461 pekerja kemudian industri sedang mampu menyerap tenaga kerja sebanyak 12165 pekerja, dari fakta ini terlihat penyerapan tenaga kerja sektor industri sangat berperan penting bagi Deli Serdang.

Peningkatan kesejahteraan masyarakat terjadi bilamana adanya pertumbuhan ekonomi pada suatu wilayah. Laju pertumbuhan rill PDRB Deli Serdang dapat ditunjukan sebagai berikut :

Tabel 4. Laju pertumbuhan rill PDRB deli serdang tahun 2012 - 2016 (dalam \%)

\begin{tabular}{rc}
\hline Tahun & Pertumbuhan rill dalam \% \\
\hline 2012 & $4,99 \%$ \\
2013 & $9,22 \%$ \\
2014 & $7,50 \%$ \\
2015 & $5,24 \%$ \\
2016 & $5,32 \%$ \\
\hline
\end{tabular}

Sumber : Deli Serdang dalam Angka 2016

Dari tabel 4 diatas laju pertumbuhan ekonomi tertinggi pada tahun 2013 yaitu sebesar 9,22\% dan terendah pada tahun 2012 sebesar 4,99\% sedangkan pada tahun 2016 tingkat pertumbuhannya sebesar 5,32\% pertumbuhan ini diatas pertumbuhan ekonomi provinsi Sumatera Utara yaitu sebesar $5,18 \%$.

Bila dilihat dari sisi sektor industri pertumbuhan sektor ini berfluktuasi hal ini dapat dilihat pada tabel 5 berikut :

Tabel 5. Laju Pertumbuhan Sektor Industri Pengolahan Deli Serdang Thn.2012-2016.

\begin{tabular}{cc}
\hline Tahun & Laju Pertumbuhan (\%) \\
\hline 2012 & 2.97 \\
2013 & 4.27 \\
2014 & 3.55 \\
2015 & 3.87 \\
2016 & 4.33 \\
\hline
\end{tabular}

Sumber: Deli Serdang dalam Angka 2016

QE Journal |Vol.06 - N o. 02 July 2017 - 111 
Dari tabel 5 diatas pertumbuhan sektor industri kelihatannya menaik pada tahun 2013 yaitu sebesar $1.3 \%$, kemudian menurun tipis selanjutnya menaik kembali pada tahun 2016 yaitu sebesar $0.46 \%$, menaiknya ini dimungkinkan karena membaiknya perekonomian Deli Serdang. Secara rata - rata untuk melihat pendapatan yang diterima setiap penduduk dapat ketahui dari PDRB perkapita, PDRB perkapita ini merupakan jumlah nilai PDRB dibagi dengan jumlah penduduk. Berikut tabel 6 menunjukan PDRB perkapita kabupaten Deli Serdang atas dasar harga konstan tahun $2012-2016$.

Tabel 6. PDRB perkapita Kabupaten Deli Serdang atas dasar harga konstan tahun 2012-2016 (Rupiah)

\begin{tabular}{cc}
\hline Tahun & PDRB / Perkapita \\
\hline 2012 & 25081088,95 \\
2013 & 26748024,30 \\
2014 & 28111864,02 \\
2015 & 28932859,74 \\
2016 & 29837900,25 \\
\hline
\end{tabular}

Sumber: PDRB Kabupaten Deli Serdang menurut lapangan usaha thn 2012-2016

Tabel 6 diatas terlihat PDRB tertinggi sebesar 29,84 juta yaitu pada tahun2016 dan yang terendah sebesar 25,08 juta yaitu pada tahun 2012, setiap tahun nilai PDRB perkapita Deli Serdang terus mengalami peningkatan. Dari angka-angka pendapatan perkapita ini wilayah Deli Serdang termasuk pada masyarakat yang teridentifikasi tidak termasuk wilayah miskin.

Hasil Estimasi Model Fungsi Sektor Unggulan Industri Terhadap Pertumbuhan Ekonomi Deli Serdang.

Nilai LQ sektor industri Deli Serdang melebihi dari satu dan cenderung terus meningkat, hal ini disebabkan wilayah Deli Serdang lokasinya berada mengelilingi wilayah ibukota propinsi Sumatra Utara yaitu Medan. Seperti yang diketahui bahwa kota Medan merupakan pusat pertumbuhan wilayah Sumatra Utara, kota ini didukung oleh fasilitas umum relative mencukupi, memiliki jalan lingkar cukup baik, pelabuhan laut Belawan bertaraf internasional memiliki fasilitas operasi yang cukup baik. Selain itu kota Medan memiliki pelabuhan udara Kuala Namu yang cukup bagus, luas dan memiliki fasilitas pendukung operasi yang baik serta bertaraf internasional. Selanjutnya dapat ditambahkan bahwa kota 
Medan memiliki tiga perguruan tinggi negeri mengasuh banyak jurusan dan program studi dan juga memiliki puluhan perguruan tinggi swasta juga mengasuh banyak jurusan dan program studi, ini artinya kota Medan menyediakan fasilitas dan tenaga kerja terampil, terdidik dan pengembang yang dapat mendukung perkembangan dan pertumbuhan industri. Didukung oleh jumlah penduduk kota Medan sebesar yaitu 2.5 juta jiwa dan tingkat pertumbuhan penduduk berasal dari tingkat kelahiran serta migrasi lumayan banyak membuat kota Medan semakin sempit dan permintaan atas tanah semakin meningkat, sehingga harga tanah di Kota Medan semakin tinggi, kondisi ini membuat para investor industri membangun industrinya dikawasan Deli Serdang. Tanah di wilayah Deli Serdang masih cukup luas, tanah-tanah pertanian tanaman padi, tanaman palawija terbentang luas diwilayah ini begitu juga dengan tanah perkebuanan sawit dan perkebunan tembakau milik PTP II yang sudah tidak diusahakan secara optimal terhampar luas, secara ekonomi tanah-tanah ini tidak diusahakan secara efisien, para petani gurem mengusahakan tanahnya hanya sekedar dapat menyambung hidup saja dan mereka rentan untuk menjual tanah mereka, para pengusaha perkebunan banyak menelantarkan tanahnya sehingga digarap oleh orang-orang yang tidak jelas identitasnya dan dimanaatkan secara tidak jelas penggunaannya pada sisi lain harga tanah di Deli Serdang jauh lebih murah bila dibandingkan dengan harga tanah di Kota Medan. Kondisi ini membuat wilayah Deli Serdang yang berbatasan dengan kota Medan banyak berdiri industri, banyak tanah-tanah pertanian di Deli Serdang beralih fungsi menjadi kawasan industri maupun wilayah hunian perumahan, sehingga kegiatan industri meningkat signifikan di wilayah Deli Serdang.Mengikuti uraian yang telah dilakukan pada kerangka teori dan studi hasil penelitian empiris dapat dibangun model fungsi sektor unggulan industri terhadap pertumbuhan ekonomi Deli Serdang. Dari olahan data yang telah dilakukan diperoleh hasil sebagai berikut.:

Tabel 7. Hasil estimasai dari model fungsi sektor unggulan industri terhadap pertumbuhan ekonomi Deli Serdang

\begin{tabular}{llllll}
\hline $\begin{array}{l}\text { Variabel } \\
\text { Bebas }\end{array}$ & Koefisien & Sdr Error & t-tes & Probability & Keterangan \\
\hline C & -9.256256 & 4.929850 & -1.877594 & 0.0759 & signifikan \\
$\begin{array}{l}\text { Sektor } \\
\text { Industri }\end{array}$ & 5.3424485 & 2.906721 & 1.837977 & 0.0818 & signifikan \\
\hline
\end{tabular}

QE Journal |Vol.06 - N o. 02 July 2017 - 113 
R square : :0,150958

Adjust R square : 0,106271

Prob F-tes : 0,08

Durbin waston star : 2,519722

Koefisien Diterminasi $\left(\mathrm{R}^{2}\right)$ sebesar 0,150958, ini menunjukan bahwa $15 \%$ variasi pertumbuhan ekonomi dapat diterangkan oleh variabel bebas yang dimasukan dalam model, variabel bebas yang dimasukan dalam model ini hanya variabel nilai LQ dari sektor industri - sektor unggulan industri oleh sebab itu kemampuan untuk menjelaskan variabel terikatnya hanya terbatas sebesar 15\% sedangkan $85 \%$ lagi diterangkan oleh variabel bebas lain yang tidak dimasukkan dalm model penelitian.

Nilai konstanta bernilai negative hal ini menunjukan bahwa tanpa ada sektor unggulan industri pertumbuhan ekonomi di Deli serdang menurun dan signifikan serta tingkat kepercayaan 95\%. Hasil estimasi fungsi pertumbuhan ekonomi Deli Serdang dipengaruhi oleh sektor unggulan industri yaitu berpengaruh positif dan signifikan dengan tingkat kepercayaan 95\% koefisien regesi sebesar 5,342485 nilai ini dapat diartikan bahwa peningkatan nilai LQ sektor industri sebsar satu satuan akan menyebabkan peningkatan pertumbuhan ekonomi Deli Serdang secara rata-rata sebesar 5,34\% dengan asumsi variabel bebas lainnya dianggap tetap.

Dalam usaha untuk meningkatkan tingkat pertumbuhan ekonomi Deli Serdang pihak pemerintah melalui Badan Perencanaan Daerah dapat melakukan usaha peningkatan nilai LQ industri, hal ini perlu dilakukan karena meningkatnya nilai LQ industri dapat meningkatkan pertumbuhan ekonomi Deli Serdang.

Teori perubahan structural menghendaki bagi Negara-negara yang masih belum maju agar berusaha merubah pola perekonomian mereka dari struktur ekonomi dimana sektor pertanian masih sangat berperan penting berusaha untuk menggantikan menjadi pola struktur ekonomi dimana sektor industri dengan berbagai fariasinya berperan penting bagi perekonomian mereka. W.Arthur Lewis mengemukakan model surplus tenaga kerja dua sektor dan Hollis B.Chenery memperkenalkan model patterns of development (pola-pola pembangunan). Mereka melakukan analisis terhadap perubahan struktur ekonomi, perubahan struktur 
ekonmi dianggap penting dalam upaya meningkatkan kemakmuran masyarakat. Berperannya sektor industri diyakini banyak ahli ekonomi dapat mempercepat dan mendorong pertumbuhan ekonomi suatu wilayah. Kuncoro 1996 bahwa Industrialisasi di Indonesia sejak PELITA I telah mencapai hasil yang diharapkan dan telah mengakibatkan adanya perubahan struktur dalam perekonomian, sektor industri memberikan kontribusi yang besar terhadap pertumbuhan ekonomi menyalip kontribusi sektor pertanian. Meningkatkan fungsi industri berkaitan dengan usaha untuk meningkatkan output yang dihasilkan suatu negara. Tambunan 2001 terdapat sejumlah indikator yang dapat dipakai sebagai alat ukur prestasi kerja dari industrialisasi diantaranya besarnya nilai tambah sektor industri, peningkatan rata-rata pertumbuhan pertahun dari sektor industri dan bertambahnya jumlah eksport output ke negara-negara lain serta meningkatnya kontribusi dari sektor industri terhadap GNP pada suatu negara.

Pada sektor industri terjadi peningkatan produk nasional akan mengakibatkan terjadinya peningkatan dalam penyerapan tenaga kerja, selanjutnya pada sektor pertanian terjadinya peningkatan produk nasional mengakibatkan peningkatan dalam penyerapan tenaga kerja hampir sama, berarti ada perbedaan pengaruh perubahan peningkatan produk nasional antara sektor pertanian dengan sektor industri. Pada sektor pertanian perubahannya hampir sama sedangkan pada sektor industri perubahan penyerapan tenaga kerja lebih besar.

Hasil analisis Chenery dan Syrquin 1950-1970 pertumbuhan ekonomi yang dialami negara berkembang - dimaksudkan disini kenaikan pendapatan perkapita dari US\$100 menjadi sebesar US\$1000 - memiliki cirri-ciri sebagai berikut :

1. Tingkat tabungan dan pebentukan modal meningkat cukup besar.

2. Tingkat pendapatan pemerintah meningkat, peningkatan ini berasal dari meningkatnya penerimaan dari pajak.

3. Pengeluaran untuk pendidikan menjadi lebih besar.

4. Arah perubahan tingkat pembentukan modal besar, arah tingkat konsumsi pemerintah meningkat tipis. 
5. Peranan sektor pertanian dalam produksi nasional menurun, peranan sektor industri bertambah tinggi dan peranan sektor jasa juga naik tetapi kecil.

6. Peranan eksport dalam kegiatan ekonomi nasional bertambah penting dan untuk eksport bahan mentah mengalami penurunan.

7. Penggunaan tenaga kerja pada sektor pertanian menunjukkan adanya penurunan, sedangkan pada sektor industri meningkat demikian juga pada sektor jasa mengalami peningkatan.

8. Terjadi perubahan proporsi penduduk yang tinggal di daerah urban, sedangakn tingkat kelahiran penduduk terjadi penurunan demikian juga tingkat kematian penduduk menunjukkan angka adanya penurunan.

9. Distribusi pendapatan menggambarkan adanya ketidak adilan $40 \%$ penduduk menerima pendapatan rendah, $40 \%$ penduduk menerima pendapatan tinggi dan $20 \%$ penduduk menerima pendapatan paling tinggi

\section{SIMPULAN}

Berdasarkan hasil analisis yang telah dilakukan dapat ditarik kesimpulan bahwa:

1. Sektor industri Deli Serdang memiliki nilai LQ $>1$ dan sektor ini merupakan sektor ekonomi unggulan bagi Deli Serdang.

2. Meningkatnya nilai LQ dari sektor industri ini dapat meningkatkan pertumbuhan ekonomi Deli Serdang.

\section{DAFTAR PUSTAKA}

Amaluddin,2012 Analisis Spesialisasi dan Pengaruhnya Terhadap Pertumbuhan Ekonomi Antar Wil-ayah di Provinsi Maluku. Fakultas Ekonomi (Internet). 2012 (Akses 16 Feb 2015). Diambil dari: http://www.amaluddin.blogspot.com

Daryono, Subagiyo. Arifin, Sri, Hascaryo. 2015, Analisis Sektor Unggulan Bagi Pertumbuhan Ekonomi Daerah di Jawa Tengah. University Reserch Colloguium. 2015 (Akses 22 September 2017) 
Didit Purnomo, Devi Istiqomah, 2008. Analisis Peranan Sektor Industri Terhadap Perekonomian Jawa Tengah Tahun 2000 dan 2004 Analisis Input Output. Jurnal Ekonomi Pembangunan Vol.9 No.2 Desember 2008 Hal.137 - 155 (Akses 22 September 2007)

Dylla Novrilasari 2008 Analisis Sektor Unggulan Dalam Meningkatkan Perekonomian dan Pembangunan Wilayah Kabupaten Kuantan Singingi (Internet). 2008 (Akses 16 Feb 2015). Diambil dari: http://www.repository.Ipb.ac.id

D S. Priyarsono, Djaimi Bakce, 2008. Industri Berbasis Pertanian: Arah Pengembangan Industri di Indonesia, Soca Volume 8 No.3 Tahun 2008 (Akses 22 September 2017)

Fatmasari Sukesti, Setia Iriyanto, 2011. Pemberdayaan UKM, Menungkatkan Komodistas Unggulan Ekspor UKM Dalam Rangka Pengembangan Ekonomi Daerah, Studi pada UKM Jawa Tengah. Seminar Nasional Ilmu Ekonomi Terapan Fakultas Ekonomi UNIMUS 2011.

Glasson John,1977Terjemahan Sihotang. Pengantar Perencanaan Regional. Jakarta: Lembaga Penebitan FE UI.

Heru Kustanto, Rina Oktaviani, Bonar M. Sinaga, M. Firdaus, 2012, Reindustrialisasi dan Dampaknya Terhadap Ekonomi Makro Serta Kinerja Sektor Industri di Indonesia , Jurnal Riset Industri Vol. VI No 12012 Hal. 97 - 115 (Akses 22 September 2017)

I Dewa Made Darma Setiawan,2007 Peranan Sektor Unggulan Terhadap Pertumbuhan Ekonomi Daerah Jawa Timur, Bali dan Nusa Tenggara Barat: Pendekatan Input Output Multiregional (Internet). (Akses $16 \quad$ Feb 2015). Diambil dari: http://www.portalgaruda.org

Kuncoro Mudradjad 1996, Analisis Struktur Prilaku pekerja Agro Industri Indonesia : Suatu Catatan Empiris. Kelola no.11NI hal 64-92.

Lionel Effion, Enang Bassey Udah 2014, Industrialization and Economic Development in A Multicultural Milieu : Lessons For Nigeria. British journal of Economics, Management \& Trade 4(11) :17721784 (Diakses 22 September 2017) 
Nasir, M. 2015. Analisis Pengaruh Sektor Unggulan Terhadap Pertumbuhan Ekonomi di Kabupaten Sumatra Utara. Proseding: Seminar Hasil Penelitian Lembaga Penelitian Universitas Negeri Medan Thn. 2015 Bidang Sain,Teknologi,Sosial,Bahasa dan Humaniora.Lembaga Penelitian Universitas Negeri Medan.

Robiani Bernadette, 2004, Analisis Pengaruh Industrialisasi Terhadap Pertumbuhan Ekonomi di Sumatera Selatan. . Jurnal Ekonomi dan Pembangunan Indonesia No.1 Vol.4 (akses 22 September 2017)

Yunie Puspita Sari M,2004 Analisis Pertumbuhan Ekonomi dan Sektor Unggulan di Kabupaten Lamongan. (Akses 23 Feb 2015). Diambil dari: http://www.researchgate.net

Samuelson, A Paul dan WilliamDN 2004. Analisis Pertumbuhan Perencanaan Regional. PT. Media Global Edukasi; Jakarta.

Sjafrizal.2012, Ekonomi Wilayah dan Perkotaan, Rajawali Padang

Tambunan Tulus 2001, Transformasi Ekonomi di Indonesia. Teori dan Penemuan Empiris. Edisi Pertama Salemba Empat Jakarta.

Tarigan Robinson. Ekonomi Regional Teori dan Aplikasi. Jakarta: Penerbit Bumi Aksara; 2012.

Todaro Michael P.2000 Ekonomi Pembangunan, Terjemahan oleh Haris Munandar. Jakarta: edisi ke lima. Bumi Aksara Jakarta. 